\title{
Job Design, Compensation and Commitment of Employee in Service Sector Organizations of Nepal
}

Gopal Man Pradhan*

\section{Abstract}

This study is based on the impact of Job design and Compensation system on employee commitment of service sectors of Nepal. The variables job design and compensation system are taken as independent variables whereas employee commitment is dependent variable. In this research work it is found that job design and compensation system have positive correlation with employee commitment. However, while analyzing the beta coefficient, it is found that sensitivity to job design is high followed by compensation system for employee commitment. It means that if Nepalese service sector invests a significant amount and effort for development of proper job design and to develop proper compensation system, they can improve employee commitment for accomplishment of assigned job in an effective way.

Keywords: Job design, Compensation system, Employee commitment, financial benefits, Nonfinancial benefits.

\section{Background}

In today's competitive environment no organization in world can perform at strength levels unless each employee is committed to the organizations' objectives and works as an effective team member. The work place is changing dramatically and demands for highest quality of products are increasing. Appointment of good workers is critical but of greater significance is the organizations ability to create a committed workforce. According to Hancock et al, (2013) commitment is the main predictor of turnover and performance; hence organizations that are concerned about employees and want to keep high performing employees should consider increasing commitment.

Job design refers to a spectrum of job factors, ranging from internal and external organizational factors to the way tasks are organized, that affect what people do at work and how effectively they can do it. Compensation is one of the key drivers of motivation because humans are naturally inclined to perform better when they perceive that they will get sufficient payment or returns from their efforts. While people exert effort for different reasons, today's competitive economic environment coupled with the consumer society has made compensation arguably the most important motivation factor. Organizational commitment is an attitude or a behavior

\footnotetext{
* Dr. Pradhan is Associate Professor, Tribhuvan University
} 
of an individual that shape the form of loyalty to the firm, and also the achievement of mission, vision, values, and goals, of the organization. Usually, it was found that there is positive impact of job design and compensation system over the commitment of employees towards accomplishment of assigned job in best possible knowledge and efficiency.

\section{Statement of Problems and Research Questions}

In these modern times, there is a lot of interest in the field of Job design, compensation management and employee commitment. Why because, employees are the most significant and valuable resource in any organization therefore, ensuring that they are satisfied with their job and give the organization their best is one of an organization's main objective. There are several ways to motivate the performance of employees; among them are to develop proper job design and to build an effective compensation management system. In every organization, employees get job based on their skills, efficiency and knowledge and typically they receive different kinds of benefits in the form of wages, salaries, bonuses, commissions etc. Most of these employees who possess good and solid educational backgrounds tend to be unmotivated to perform their best with the job when they do not get job that is supportive for future career development and their compensation package does not measure up to their educational background and standard thus leading to dissatisfaction, withdrawal behaviors, and turnover.

Organizations with more appropriate and adequate compensation packages typically record a positive effect on employee which leads to an overall decrease in turnover and employees' willingness to remain with such organizations. This could imply that proper compensation packages would motivate employees to commit to the organizations they work for and remain loyal to it. This study is aimed at exploring the gap between the job design, compensation management system and organizational commitment by examining the forms of job design and compensation that the organizations disburses, the factors that influence organizational commitment in organizations and finally, the existing significant relationship between job design and compensation management with that of organizational commitment in organizations. The ability to identify the plausible reasons as to how and why proper job design and compensating employees adequately can lead to organizational commitment on the part of employees pushes us a step further and closer to understanding the importance of job design and compensation management and how they greatly influence organizational commitment in the service sector organizations. The study of statement of problems of past study the following questions may come into existence in the study:

- What is the situation of job design and compensations systems in service sector organization in Nepal?

- What is the impact of job design on employee commitment in service sector organization in Nepal

- What is impact of compensation system on employee commitment in service sector organization in Nepal? 


\section{Research objective}

The main objective of this research study is to assess the job design and compensation system in service sector organizations of Nepal and know their impact on employee commitment of accomplishment of assigned in an effective way. However, the following are the specific study of this research work.

- To know the situation of job design and compensations systems in service sector organizations in Nepal

- To assess the impact of job design on employee commitment in service sector organizations in Nepal

- To examine the impact of compensation system on employee commitment in service sector organizations in Nepal.

\section{Significance of the Study}

The emerging concept of globalization has provided many opportunities as well as challenges to the entrepreneurs and also to the employees. Entrepreneurs can get employees from various sources inside and outside the region or even the countries based of requirements to promote business. Similarly, people can get employment opportunities based on their academic qualification, experience and skills not only in the country but also in different parts of the world. This study might give an insight on the relationship between job design, compensation and commitment of employees in the context of least developed country like Nepal, and in service sector organization. The success of the business organization largely depends on the effectiveness and quality of the services that they provide to the customers. Keeping these views into consideration, this study is expected to be fruitful to explore the job design and compensation practices that exist in service sector organizations and their effects on employee commitment for accomplishment of assigned job. Employee commitment is taken as an importance source of competitive strength of the organization because committed employees do the assigned job according to the best of their ability and skills.

\section{Limitations of the Study}

In this study the researcher is considered appropriate research methodologies to come up with reliable result. But, there may be some notable research limitations, which are mentioned as:

- This study is based on primary data collected from limited service sector organization which may not represent to all the institutions.

- In this study on job design and compensation system is taken for study so only these two variables may not be sufficient for judging commitment of employees.

- All the information and data used in the study are collected from primary sources through survey method; therefore, the validity of the data depends upon the individual perception of the respondents.

- This study is made to know about the effect of job design and compensation on employee commitment but there are other factors may impact on commitment of employee. 


\section{Literature review}

Compensation management is one of the most fundamental human resource practices in management and a major subject of importance in the general field of management. This comes as no surprises considering the fact that most if not all employees accept job opportunities mostly because of the compensation being offered to them. The literature suggests that positive work related behaviour and attitudes largely depends on employee perceptions on extend their employer values their contribution and cares about their wellbeing (Allen and Wright, 2007). Compensation is a broad idea that can include anything an employee may value and desire that an employer is able or willing to offer in exchange for employee contribution (Henderson 1989). The productivity of an organization and human resource management has a direct relationship with each other. If employees are managed appropriately i.e. job analysis, recruitment, training, motivational tools like compensation etc. they are destined to give high performance in their operations so will improve the overall productivity of the organization (Ichniowski et.al, 1997). While Thomas E. Catanzaro (2001) in his article Compensation and Motivation described the effects of rewards over employee motivation. The concept has roots in psychological research and theories of work motivation to improve employee satisfaction and performance and therefore increase organizational productivity and efficiency (Campion, Mumford, Morgeson \& Nahrgang, 2005).

In the view of Opatha (2002), 'Job design is the functions of arranging task, duties and responsibilities in to an organizational unit of work'. The working definition for the study purpose is that, "The job design is the way to organize the contents, methods and relationship of jobs in order to achieve organizational goals and objectives as well as satisfaction of job holders. There are various approaches to job design. Regarding this Aswathappa (2016) explained that, various approaches to job design are namely; Job Rotation, Job Engineering, Job Enlargement, and Job Enrichment. The sense of job significant, feeling important in eyes of others, realizing ones' competence, and freedom to make decisions are positively related to performance (Ambrose et al, 2013). This study focused only skill variety, task identity, task significance, autonomy and feedback as the dimensions of job design. Much of the research centers on employee perceptions of tasks, the relationships between those perceptions and the behavioral outcomes as a result of those relationships (Griffin, Welsh \& Moorhead, 1981).

Employee Commitment is the psychological attachment and the resulting loyalty of an employee to an organization. A large numbers of studies have been conducted to investigate the concept of organizational commitment. Still, commitment is the most challenging and researchable concept in the fields of management, organizational behavior. There have been several measures and definitions about employee commitment. Meyer and Allen (1991) described three dimensional model of commitment: Affective, Continuance and Normative. He said Affective Commitment is based on how much individual 'want' to remain in the organization. Continuance Commitment refers to an awareness of the costs associated with leaving the organization. Continuance commitment based on individual having to remain with the organization lost their previous investment before gone. Normative Commitment 
reflects a feeling of obligation to continue employment. Employees with a high level of normative commitment feel that they ought to remain with the organization. To remain competitive in the face of these pressures employee commitment is crucial. Without employee commitment there can be no improvement in any business area. To succeed in the face of increasing competition organizations need improved productivity at all levels. This requires commitment on the part of all employees which can only be achieved through better management practices in the area of managing rewards and compensation, by creating a perception of fairness through competitive wages and benefits (Colbert, 2004).

Oneof thechallengesfacing modernorganizationsinvolves maintainingemployeecommitment in the current competitive pressures. With no assurance of continued employment, employees have now raised their expectations in other areas. For instance employees expect employers to demonstrate their commitment in terms of pleasant working environment where a fair and just reward and compensation provides employees with the baseline requirements met to go for higher things like job satisfaction and fulfillment hence enhancing organizational commitment (Harter et. al, 2002).

\section{Framework of the Study}

This study focused on skill variety, task identity, task significance, autonomy and feedback as the dimensions of job design and similarly compensation involves both financial reward and non-financial rewards and benefits. The employee commitment may be represented by affective, continuance and normative commitment. Based on the study of various literatures, the research framework is presented as follows:

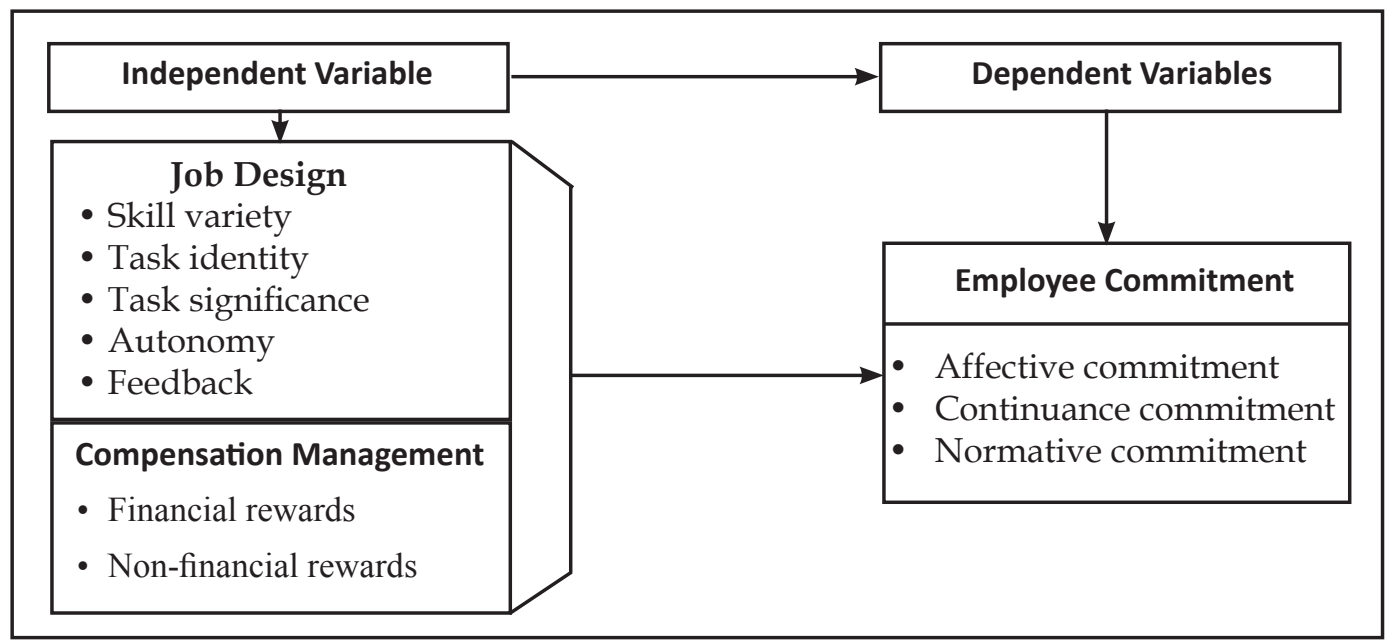




\section{Nature of Research}

This study is based on primary data obtained by distributing questionnaires to selected respondents. Therefore, it is descriptive, co-relational, causal comparison type of research. In this research some selected job design and compensation related variables have been taken into account for getting feedback from both managerial and assistant level employees of Nepal Telecom Company Ltd. and Ncell Pvt. Ltd. In this study it is tried to find out the impact of job design and compensation system of the organization on employee commitment.

\section{Research Design}

The research designed adopted in this study consists of descriptive, co-relational, and causal comparative research design to analysis the various issues are raised. The descriptive research design is used for the purpose of fact-finding, conceptualization, description, and operation searching for adequate information in the context of job design and compensation system and their impact on employee commitment in Nepalese service sector organizations. The research design adopted in this is identical as the previous researches taken place, for example (Amstrong, 2012). Guest, 2002, DeNisi , and Griffins (2008) showing the effect of job design, compensation and other variables on employee commitment and performance.

\section{Research Hypothesis}

The broad objectives of this study are to explore the relationship between the job design and compensation system on employee commitment of Nepalese service sector organizations specially telecom sectors. Its objective is also to compare the result obtained in the public and private service sector organizations. On the basis of above objectives and relation, following hypotheses are explored:

Hypothesis 1: There is a positive and significant relation and effect of job design and employee commitment.

Hypothesis 2: There is a positive and significant relation and effect of compensation system on employee commitment.

\section{Sources and nature of data}

For the purpose of fulfillment of the objectives of the research, necessary data and information was collected through primary sources i.e. questionnaire. Data used in this study were collected from Nepal Telecom Company Ltd. and Ncell Pvt. Ltd. In this survey research, three categories of information namely detail information of respondents, job design and compensation, and employee commitment were collected. The questionnaire was developed from prior literature as used by Guest, 2002. Basically, normative theory of maintaining link between job designs, compensation system and employee commitment was taken into account in this research work. 


\section{Population and Sample size}

The tools are used by the researcher with the help of academician friend circle and recommendation from professionals. The researcher explained the purpose of the study and all aspects of the questionnaire to the respondents. The selected respondents are employees working in different levels consisting of managerial, officer and assistant level of both in head office and branch offices in different part of the country. They are made to understand that all information being provide would be treated with confidentially and for the purpose of research only. In this study, employees of Nepal Telecom Company Ltd. and Ncell Pvt. Ltd. are taken into account as samples to analyze. In total 462 questionnaire have been distributed and $396(85.71 \%)$ copies that are completely filled and returned are utilized for the purpose of the study.

\section{Effect of job design and compensation on employee commitment}

In this regression model employee commitment is considered as dependent variable $Y$ and two variables consisting of job design and compensation system are considered as independent variables. The following multiple regression table shows the effect of two variables on employee commitment:

\begin{tabular}{|l|c|c|c|c|c|}
\hline \multirow{2}{*}{ Model } & \multicolumn{2}{|c|}{$\begin{array}{c}\text { Unstandardized } \\
\text { Coefficients }\end{array}$} & \multirow{2}{*}{$\mathrm{t}$} & \multirow{2}{*}{ Beta } & \multirow{2}{*}{ Sig. } \\
\cline { 2 - 3 } & $\mathrm{B}$ & Std. Error & & & \\
\hline 1 (Constant) & 7.342 & 0.623 & & & $0.000^{* *}$ \\
Job Design (JD) & 0.225 & 0.048 & 4.252 & 0.265 & $0.005^{* *}$ \\
Compensation System (CS) & 0.190 & 0.056 & 4.117 & 0.248 & $0.030^{*}$ \\
\hline & & & & & \\
\hline R=0.421, ${ }^{R^{2}=0.332, \text { Adjusted }{ }^{R^{2}}=0.265, \text { F- Value }=24.121}$ \\
Note: ${ }^{*} \mathrm{p}<0.05,{ }^{* *} \mathrm{p}<0.01$
\end{tabular}

a. Dependent Variable: Employee motivation

$\mathrm{Y}=\mathrm{a}+\mathrm{bJD}+\mathrm{bCS}+\mathrm{e}$

$$
=7.342+0.225 \mathrm{JD}+0.190 \mathrm{CS}+\mathrm{e}
$$

$\mathrm{T}=(7.342),(4.252),(4.117)$

p- value $=0.005^{* *}, 0.030^{*}$

$R=0.421, R^{2}=0.332$, Adjusted $R^{2}=0.265, F-$ Value $=24.121$

Overall p-value $=0,000^{* *}$ 
The $\mathrm{R}^{2}$ is 0.332 . It means that only $33.2 \%$ of the total variation is explained by this model and other part of explanation is made by other variables which are not included in this study. The F- value is 24.121 and overall p-value is 0.000 . Thus, the multiple regression model used in this study is fit and appropriate because ANOVA table shows that the F- value is significant at $5 \%$ level of significant.

The calculated p-values of job design and compensation system are 0.005 and 0.030 respectfully which are significant at $5 \%$ level of significant. Therefore, both two variables are the predictors of the employee motivation. While analyzing the beta coefficient, single variable job design's sensitivity to employee commitment is high (0.265) followed by compensation system (0.248) therefore both variables have positive impact on employee commitment. However, job design has more impact on employee commitment as compare to compensation system developed by the service sector organizations.

\section{Summary of the study}

In study multiple regression model is used to know the effect of Job design and compensation on commitment of employees where the $\mathrm{R}^{2}$ is 0.332 , it means that only $33.2 \%$ of the total variation is explained by this model and other part of explanation is made by other variables which are not included in this study. The F-value is 24.121 and overall p-value is 0.000 . While analyzing the beta coefficient, single variable job design's sensitivity to employee commitment is high followed by compensation system. Thus these two variables are considered as valuable and significant predictor of employee commitment towards their job assignment. In conclusion research found that all two variables consisting of compensation system and job designs have positive impact on employee commitment in service sector organizations.

The primary purpose of this study was to evaluate the impact of job design and compensation system as best HR practices on commitment is identified by Pfeffer (1994) and Guest, 2002). Based on Guest (2002), researcher hypothesizes that the following practices are related to employee commitment: compensation system and job design. Regression coefficients of compensation system and job design positively contribute to organizational performance explained by employee commitment. This may mean that Nepalese service sector organizations try to identify competent candidates to get into the organization. It means that if Nepalese service sector organizations invest a significant amount and effort for development of proper job design and to develop proper compensation system, they can improve employee commitment. This finding is consistent with the findings of Guest (2002). 


\section{References}

Allen, M. R., \& Wright, P. (2007). Strategic management and HRM. In Boxall P. Purcell, J. and Wright, P. (Eds.), The oxford handbook of human resource management. New York: Oxford University Press.

Adhikari, D.R., \& Mueller, M. (2005). Human resource management in Nepal. In Budhwar.

Ambrose, K. G., Nehemiah, B.C. , \& Augustine, R. (2013). Skill variety, feedback

and employee performance: A case of Moi teaching and referral hospital

Armstrong, M. (2012). Strategic human resource management: A guide to action. Philadelphia: Kogan Page Publishers.

Aswathappa, K. (2016). Human resource and personal management (4th ed.). India: Tata McGrawHill Publishing Company Limited.

Campion, M.A., Mumford, T.V., Morgeson, F.P., Nahrgang, J.D. (2005). Work redesign: Eight obstacles and opportunities. Human Resource Management, 44(4), 367-390. https://doi.org/10.1002/hrm.2008

Catanzaro, T.E. (2001). Compensation \& Motivation. Journal of Veterinary Emergency and Critical Care, 11, 62-65.

DeNisi A.S., \& Griffins R.W. (2008). Human resources management. Boston, New York: Houghton Miffling Company.

Dessler, G. (2014). Human resource management. Upper Saddle River, NJ: Pearson/Prentice Hall.

Griffin, R.W., Welsh, A., \& Moorhead, G., (1981). Perceived task characteristics and employee performance: A literature review. The Academy of Management Review, 6(4), 655-664.

Guest, D. (2002). Human resource management, corporate performance and employee wellbeing: Building the worker into HRM. The Journal of Industrial Relations, 44(3), 335-358

Hancock, J.I., Allen, D.G. Bosco, F.A,McDaniel,K.R., \& Pierce, C.A. (2013). Metanalytic view of employee turnover as a predictor of firm performance. Journal of Management,39(3)

Henderson, R.I. (1989). Compensation management: Rewarding performance. Reston, Virginia: Reston Publication

Ichniowski, C., Thomas A.K., Levine, D., Olson, C., \& Strauss, G. (1997). What works at work: Overview and assessment. Industrial Relations, 35, 299-333.

Opatha, H.H. (2002). Performance evaluation of human resource (1st ed.). Colombo, Sri Lanka: The Author publication.

Meyer, J., \& Allen, N. (1991). A three component conceptualisation of organizational commitment. Human Resource Management Review, 1, 61-89 
Pant, P.R. (1983). Industrial relation in Nepal: A comparative study of public and private undertaking in the jute industry, India: Department of Public Administration, Punjab University.

Pfeffer, J. (1994). Competitive advantage through people: Unleashing the power of the workforce. International Journal of Human Resource Management, 8, 263-276.

Colbert, B.A. (2004). The complex resource-based view: Implications for theory and practice In strategic human resource management. Academy of Management Review, 29, 341358.

Harter, J.K., Schmidt, F.L., \& Hayes, T.L. (2002). Business-unit-level relationship between employee satisfaction, employee engagement, and business outcomes: A metaanalysis. Journal of Applied Psychology, 87, 268-279. 